\title{
INVESTIGATIONS ON INVASIVE NEMATODES ASSOCIATED WITH COMPLEX INSECT PESTS FROM SOIL IN CORN IN THE ENVIRONMENTAL CONDITIONS OF THE REPUBLIC OF MOLDOVA
}

\author{
Elena Iurcu-Straistaru ${ }^{1}$, Nicola Sasanelli ${ }^{2}$ Ion Toderaş $^{1}$, Alexei Bivol ${ }^{1}$, \\ Vasile Maticiuc $^{3}$, Stefan Rusu ${ }^{1}$, Cristina Andoni ${ }^{1}$ \\ ${ }^{1}$ Institute of Zoology, Chisinau, Republic of Moldova \\ e-mail: iurcuelena@mail.ru \\ ${ }^{2}$ Institute for Plant Protection, C.N.R., Bari, Italy \\ ${ }^{3}$ Phytotechnical Institute "Porumbeni”, Pascani village, Criuleni district, Republic of Molodova
}

\begin{abstract}
Corn is one of the major technical field crops in the Republic of Moldova, advantageous in bioecological and productive aspects, which is invaded annually by the harmful organisms with considerable parasitic impact. The phytosanitary control results, carried out annually and seasonally, comparatively in the corn plantations, notice a significant diversity of the specific diseases and of the invasive insects that seriously affect the plants from the germination phases until the harvest. In corn, were established the numerical density values (D. n.), comparative in different ecological areas, on average 15-280 (ex. $/ 100 \mathrm{~g}$ soil), with an abundance by $5-25 \%$ higher in the autumn than in the spring. Phytoparasitic impact indices the frequency (F \%) and intensity (I \%) of the phytohelminthological disease level was estimated, being more advanced by $3-30 \%$ in the spring-summer period, observed differently depending on the area compared to the autumn period. The structure of parasitic phytonematode complexes was determined counting 20 species, included in 8 families and one order (Tylenchida), classified according to trophic specialization, with the predominance of endo-ectoparasites. It was established the diversity of the associated invasive insect species from the soil: 12 species, 8 families, 3 orders, also, with invasive ectoparasitic impact on corn plants, with the disease degree of $5-40 \%$, detected in all phases of vegetation and sectors investigated.
\end{abstract}

\section{Introduction}

Corn cultivation in the Republic of Moldova is of universal importance for the primary and secondary finished product used in alimentation, in livestock sector and various industries. It is advantageous due to the high production capacity compared to other cereal crops; it has advanced ecological plasticity; is an efficient precursor for some field crops, absolutely mechanized cultivation techniques, with high rates of organic fertilizers use, minerals and water; various facilities for the caryopsis use and marketing of production and as seed material $[5,12,15]$.

These advantages are conditioned by the bioecological adaptation qualities in impact with abiotic stress factors such as: relative tolerance to drought and heat, mechanical resistance; extended leaf area, mechanisms that ensure efficient water consumption, homeostasis regulation and induction of specific resistance. As disadvantage is the attack of a large number of harmful organisms, including communities of parasitic nematodes associated with complex pest insects from the soil, even in the first stages of growth (germination - formation of 3-5 leaves), which cause serious damage to corn annually $[2,4,5,12,17,23,25,26]$.

The phytosanitary biological control, performed periodically on corn plantations is essential for the detection of nematodes and insects invasive associations, for elaboration of prognosis 
and remedial application to adjust the parasitic impact on the host plant. Successful management of nematode complexes and harmful insects from soil, ensures the development of an effective program of integrated protection management, which is based on keeping the population of harmful organisms below the economic threshold of damage, to be harmless to the entire agroecosystem $[1,2,4,15,23,26]$. The respective investigations were carried out in various areas and sectors of corn and seeds production, compared to the experimental investigated sectors in improvement and approval conditions of new forms and hybrids within the Phytotechnical Institute "Porumbeni". Our purpose was to carry out phytosanitary monitoring of invasive nematodes and harmful insect complexes in maize, compared to various productive sectors, nurseries, soils of experimental approval, with the establishment of the level of parasitic impact in the technological management of integrated protection procedures, according to the economic damage threshold. Based on the mentioned purpose, we set the following research objectives:

- the diversity and structure estimation of parasitic nematode complexes associated with harmful insect species in provoked impact of agroeconomic importance to corn growing;

- carrying out phytosanitary records in establishing the degree of invasive helminthological and entomological parasitic impact on corn, comparative depending on areas, productive, experimental and demonstration sectors.

\section{Materials and methods}

The investigations were carried out by mutual agreement between the "Seminology corn", "Technology" laboratories, the Phytotechnical Institute "Porumbeni" and the "Parasitology and Helminthology" laboratory, Institute of Zoology, 2019-2021 (figures 1-6).

In the field, the evaluation of ameliorating corn seeds and perspective hybrids was carried out, various productive and seeding sectors with an area of over 600 ha were investigated, distributed in experimental soils, homologation lands of newly created hybrids, suitable for cultivation areas. Breeding forms and productive perspective hybrids are located in three repetitions on plots with an area of 4,9 $\mathrm{m} 2$ and a density of 55-65 thousand plants per ha (30-35 plants on a row). There were researched more than 350 approved and perspective corn hybrids, 260 parental forms and 60 homozygous lines, used in the breeding process. Comparatively, the corn hybrids were studied, homologated and perspective from the Northern area (Pelenia v., Drochia d.), State Station for the field crops testing and homologation. Seed registration was performed according to the classification scale after the corn's reaction to nematode complexes and pest insect species. The corn was monitored periodically, immediately after the germination of caryopsis (10-12 days until the formation of 8-10 mature leaves), with phytosanitary assessments. Over 300 soil samples were taken, at a depth of $15-30 \mathrm{~cm}$, and the parasitically affected plants. The establishment of the helminthological and entomological parasitic disease was performed visually in the field with the help of a magnifying glass (optical degree, 100 $\mathrm{MM}$ ), and in order to ascertain the criteria of extensiveness and the level of attack, indices of parasitic disease were used, using the values of number density (D. n./m2, plant), frequency 
$(\mathrm{F} \%)$, intensity $(\mathrm{I} \%)$, reflecting the extent of the attack (GA\%), reported in $\mathrm{m} 2$, with the analysis of 100 plants/10 samples, by finding the diseases at the level of root or plant, using the gradation of 5 balls ( 0 balls - no attack, 4 balls - serious diseases $>50 \%$ ). Subsequently, the soil and plant samples taken, were subjected to laboratory analyzes by additional observations, using the binocular magnifier MBS - 10 and the binocular microscope, and highlighting the level of phytoparasitic, plant diseases was confirmed with the Canon EOS 1000 D camera [2, $4,8,9,10]$.

The study of the faunal material collected and labeled preventively, was investigated according to the classical and current methods adapted in accordance with the requirements of the "Parasitology and Helminthology" laboratory, for helminthic and entomological laboratory analyzes. The nematological analyzes were performed with the methodological installation "Baermann funnel", by flotation - decantation - filtration through sets of sieves, with various perforations sizes, specific for some nematode taxa, extracts from the soil and affected organs. Then, they were listed according to the evidence, were fixed and determined by the trophic spectrum and taxonomic affiliation, using current identification keys $[1,2,6,13,16,19]$.

The methods of evidence on corn pests with soil and plant samples collecting were performed, depending on the sector's area, each 10 plants and soil from the rhizosphere, according to the diagonal repetition, where was noted the presence of beetles (larvae, adults), lepidoptera (larvae), dipterans, himenoptera. The density of detected pests and the affection's degree on the corn plants in the ontogenetic dynamics was highlighted. Subsequently, in laboratory conditions, some structural peculiarities were established, the taxonomic affiliation was determined, as well as the abundance and the disease level on various organs, the trophic specialization spectrum, by documenting and taking pictures. To confirm the taxonomic identity of the collected insects, the entomology publications were used [3, 7, 10, 13] as well as identification keys [18, 22 etc.].
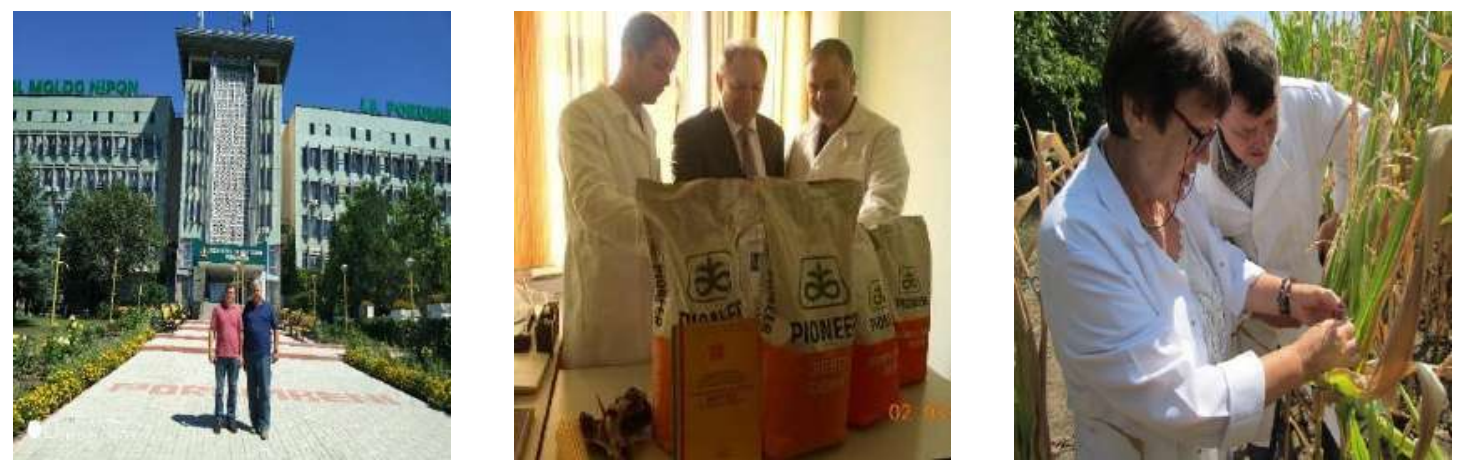

Figures 1-3. Research and teaching activities, mutual collaboration in the laboratory and in the demonstration sector with new hybrids, Phytotechnical Institute "Porumbeni", 2019-2021 

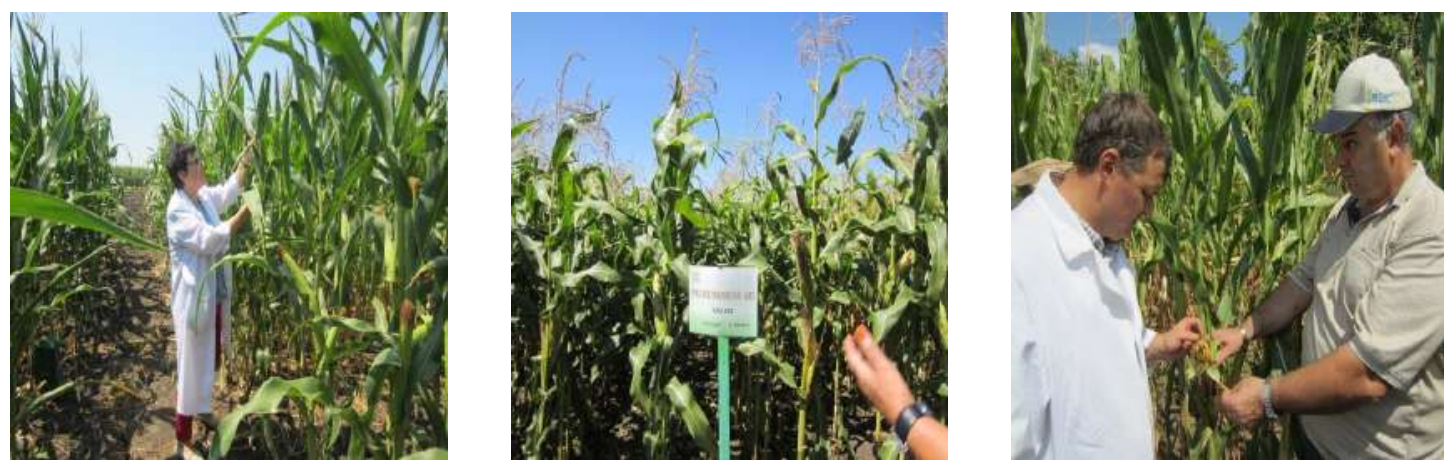

Figures 4-6. Experimental sectors phytosanitary investigated for the presence of invasive nematodes and affections caused by pests in corn, Phytotechnical Institute "Porumbeni", (Pascani v., Criuleni d.)

\section{Results and discussions}

The appearance and onset of helminthological diseases and polyphagous insects in corn, in the environmental conditions of the Republic of Moldova, are primarily determined by unstable climatic factors, quickly extensiveness and parasitic impact of pests. In the case of the onset of helminthotic diseases, with specific pathogenic and non-pathogenic effect, such as: pratylenoses, heteroderoses, tilenoses, accompanied by complexes of beetles and lepidoptera from the soil, periodically affect the plants, because the leaves absorb all nutrients from the stem to form berries, which causes the leaves to dry out, the stems to fall off, premature breaking, damage that diminishes the total yield of the corn crop. These associations of helminthic invasive agents and harmful insects on corn are in the attention of branch researchers, who frequently carry out investigations of phytosanitary records, which are included in research programs in the field of phytotechnics and breeding processes in creating forms, inbred lines, new corn hybrids, with resilience and tolerance to environmental stress factors. According to bibliographic sources, the corn crop causes damage annually, over 200 species of harmful organisms, of which 20-25 species are very dangerous, invasive, and in unstable climate conditions are manifested as significant pests of corn plants depending on the area, precocity, seed material, hybrid, environmental factors $[3,7,11,14,13,21]$.

Phytosanitary records on corn areas and sectors were carried out periodically, from the third decade of April - May - June - July - August. The May-June months were characterized by periodic abundant rainfall, slight increase in temperature, which determined the abundance of reproductive potential of hatching of invasive larvae, with aggressive infestation capabilities in plants, increasing the degree of parasitic helminthological impact, already in the formation phases of leaves, stems until the formation of panicle and cobs. In these months, late spring summer the phytohelminthosis symptoms remain accentuated, more advanced and extensive by the dynamics of visual disorders of yellowing, low number of mature leaves, poorly developed, dwarfs with roots severely affected by necrosis and specific rot, caused by helminths. The frequency and intensity values of parasitic helminthic impact advance from $3 \%$ to $25 \%$, which 
indicates the damage of more advanced corn plantations in the early stages (germination, 5-8 adult fungi), according to the sensitivity of plants to frequent frosts and instability of factors.

The estimated values in Table 1, characterize the comparative indices of the parasitic impact degree, by numerical density (D. n. ex./100g soil), frequency of diseases (F\%), intensity of degree of attack (I \%), reflecting the extent of the attack, compared to the number of soil samples analyzed and plants per $\mathrm{m} 2$, compared with sectors and areas investigated. The numerical density (D. n.) of the parasitic nematode complexes is by $10-25 \%$ higher in the II-III decade of June than in May, respectively and the frequency and intensity of the degree of attack is more advanced in the summer, being facilitated by favorable environmental conditions, high prolificacy and available food ration (tab. 1, fig. 7). These investigations are important for establishing a qualitative and quantitative diagnosis of the parasitic helmitological impact, for the elaboration of forecasts in the application of integrated protection measures, in the capitalization of corn with various precocity and cultivation areas.

Table1. The comparative indices estimation of helminth parasitic impact on corn cultivation, in average values by investigated areas and districts, May-August, 2020

\begin{tabular}{|c|c|c|c|c|c|c|c|c|c|c|c|c|}
\hline \multirow[b]{2}{*}{$\begin{array}{c}\text { Areas and } \\
\text { districts } \\
\text { investigated }\end{array}$} & \multicolumn{3}{|c|}{ May 25, 2-3 leaves } & \multicolumn{3}{|c|}{ June $20,5-10$ leaves } & \multicolumn{3}{|c|}{$\begin{array}{l}20 \text { July, flowering - } \\
\text { pollination }\end{array}$} & \multicolumn{3}{|c|}{$\begin{array}{l}\text { August } 25 \text {, caryopsis } \\
\text { formation and ripening }\end{array}$} \\
\hline & $\begin{array}{l}\text { D.n. } \\
\text { (100 g } \\
\text { sol) }\end{array}$ & $\begin{array}{l}\text { F. } \\
(\%)\end{array}$ & $\begin{array}{l}\text { I. } \\
(\%)\end{array}$ & $\begin{array}{l}\text { D.n. } \\
(100 \mathrm{~g} \\
\text { sol) }\end{array}$ & $\begin{array}{l}\text { F. } \\
(\%)\end{array}$ & $\begin{array}{l}\text { I. } \\
(\%)\end{array}$ & $\begin{array}{l}\text { D.n. } \\
\text { (100g } \\
\text { sol) }\end{array}$ & $\begin{array}{l}\text { F. } \\
(\%)\end{array}$ & $\begin{array}{l}\text { I. } \\
(\%)\end{array}$ & $\begin{array}{l}\text { D.n. } \\
(100 \mathrm{~g} \\
\text { sol) }\end{array}$ & $\begin{array}{l}\text { F. } \\
(\%)\end{array}$ & $\begin{array}{l}\text { I. } \\
(\%)\end{array}$ \\
\hline $\begin{array}{l}\text { North, } \\
\text { Drochia d., } \\
\text { Pelinia v. }\end{array}$ & $15-30$ & $10-15$ & $3-10$ & $40-180$ & $15-25$ & $10-15$ & $30-150$ & $12-17$ & $10-12$ & $120-250$ & $15-30$ & $12-18$ \\
\hline $\begin{array}{l}\text { Center, } \\
\text { Criuleni d. }\end{array}$ & $50-80$ & $5-10$ & $3-7$ & $60-180$ & $10-17$ & $7-12$ & $50-180$ & $3-10$ & $3-7$ & $140-280$ & $10-20$ & $7-12$ \\
\hline $\begin{array}{l}\text { South-East, } \\
\text { Căușeni d., } \\
\text { Grigoriev- } \\
\text { ca d. }\end{array}$ & $40-100$ & $7-20$ & $10-15$ & $70-150$ & $15-28$ & $12-15$ & $20-90$ & $15-20$ & $10-12$ & $80-180$ & $15-25$ & $10-15$ \\
\hline $\begin{array}{l}\text { South, } \\
\text { Ceadîr-Lun- } \\
\text { ga, t. Svet- } \\
\text { loe v. }\end{array}$ & $60-120$ & $5-15$ & $7-10$ & $130-240$ & $12-20$ & $8-12$ & $40-130$ & $10-15$ & $7-10$ & $40-90$ & $10-20$ & $8-13$ \\
\hline
\end{tabular}




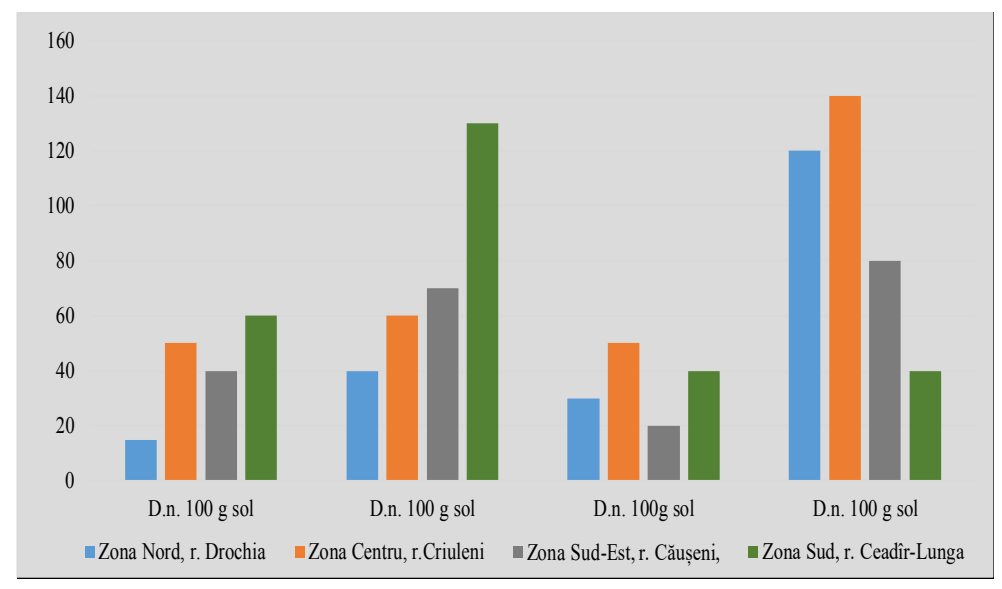

Figure 7. Estimation of the nematodes number density indices, established on corn, by areas, administrative districts, in the growth and development phases in the period 25 May - 25 August 2020

Successful management of harmful organisms is ensured by the application of a permanent phytosanitary control program and integrated protection procedures, which includes a number of components, including ways to regulate by reducing the number and parasitic impact. The approach in phytosanitary practice of the integrated management of harmful organisms is based on keeping the population of the harmful organism below the economic damage threshold, with periodic control records. Another important aspect in completing the helminthological investigations in corn is the study of establishing the frequency and structure of the parasitic nematode complexes noticed in the researched corn plantations. For the first time in the Republic of Moldova, these corn researches were performed related to the establishment of parasitic impact indices with specialized parasitic nematodes adapted to corn and the taxonomic abundance on investigated areas with their distribution according to the trophic spectrum of specialization, reflected in the table number 2. The results of taxonomic analyzes showed the presence of 21 species from 8 families with diverse trophic specialization (endo-ecto-semiendoparasite), migratory and sedentary.

It was highlighted the presence of species from the families Hoplolaimidae, Paratylenchidae, Telotylenchidae, Criconematidae, Neotylenchidae, Tylenchidae, present in the late spring-summer periods in various forms and biological stages extracted both from the soil and from the roots of plants (fig. 10). All species were classified according to parasitic trophic specialization in 5 groups, with the predominance of endo- and ectoparasitic forms of absorbent bristles, according to the mode of adaptation, growth phase, biotope, environmental factors $[4$, $8,19,20,21]$. 
Table 2. Taxonomic analysis results of parasitic phytonematode communities detected in corn, comparative on investigated areas, $2019-2021$

\begin{tabular}{|c|c|c|c|c|c|}
\hline $\begin{array}{l}\text { Taxonomic name of the species } \\
\text { detected }\end{array}$ & $\begin{array}{l}\text { Phytoparasitic tro- } \\
\text { phic specialization }\end{array}$ & $\begin{array}{l}\text { North } \\
\text { area }\end{array}$ & $\begin{array}{l}\text { Center } \\
\text { area }\end{array}$ & $\begin{array}{l}\text { South - East } \\
\text { area }\end{array}$ & South area \\
\hline $\begin{array}{l}\text { I. Pratylenchidae fam.: } \\
\text { 1. P. subpenetrans } \\
\text { 2. P. nanus } \\
\text { 3. P. curvatus } \\
\text { 4. P. hamatus }\end{array}$ & $\begin{array}{l}\text { Migrants - } \\
\text { endoparasites }\end{array}$ & $\begin{array}{l}++ \\
++ \\
+ \\
+\end{array}$ & $\begin{array}{l}++ \\
++ \\
++ \\
+\end{array}$ & $\begin{array}{c}++ \\
++ \\
++ \\
+\end{array}$ & $\begin{array}{l}++ \\
++ \\
+ \\
+\end{array}$ \\
\hline $\begin{array}{l}\text { II.. Paratylenchidae fam: } \\
\text { 5. P. cuvitatus } \\
\text { 6. P. aciculus } \\
\text { 7. P. nanus } \\
\text { 8. P. tenicaudatus }\end{array}$ & $\begin{array}{l}\text { Migrants - } \\
\text { ectoparasites }\end{array}$ & $\begin{array}{l}+ \\
- \\
++ \\
+\end{array}$ & $\begin{array}{l}+ \\
+ \\
++ \\
+\end{array}$ & $\begin{array}{l}++ \\
+ \\
+ \\
+\end{array}$ & $\begin{array}{l}++ \\
++ \\
+ \\
-\end{array}$ \\
\hline $\begin{array}{l}\text { III. Hoplolaimidae fam.: } \\
\text { 9. Helicotylenchus digonicus } \\
\text { 10. H. dihistera } \\
\text { 11. Rotylenchus agnetis } \\
\text { 12. R. incultus }\end{array}$ & $\begin{array}{l}\text { Semi-endopara- } \\
\text { sites, nutrients } \\
\text { absorbing bristles }\end{array}$ & $\begin{array}{l}++ \\
++ \\
++ \\
+\end{array}$ & $\begin{array}{l}++ \\
++ \\
+ \\
++\end{array}$ & $\begin{array}{l}++ \\
+ \\
++ \\
++\end{array}$ & $\begin{array}{c}+ \\
++ \\
++ \\
+\end{array}$ \\
\hline $\begin{array}{l}\text { IV. Fam. Telotylenchidae: } \\
\text { 13. Amplimerlinius dubius } \\
\text { 14. Merlinius brevidens } \\
\text { 15. Bitylenchus parvus }\end{array}$ & $\begin{array}{l}\text { Ectoparasites of } \\
\text { absorbent bristles }\end{array}$ & $\begin{array}{l}- \\
+ \\
+\end{array}$ & $\begin{array}{l}+ \\
+ \\
+\end{array}$ & $\begin{array}{l}+ \\
+ \\
+\end{array}$ & $\begin{array}{l}+ \\
+ \\
-\end{array}$ \\
\hline $\begin{array}{l}\text { V. Criconematidae fam.: } \\
\text { 16. Mezocriconema xenoplax } \\
\text { 17. Xenocriconemella macrodora }\end{array}$ & $\begin{array}{l}\text { Ectoparasites of } \\
\text { absorbent bristles }\end{array}$ & + & $\begin{array}{l}+ \\
+ \\
\end{array}$ & $\begin{array}{l}+ \\
+ \\
+\end{array}$ & $\begin{array}{l}+ \\
+\end{array}$ \\
\hline $\begin{array}{l}\text { VI. Neotylenchidae fam.: } \\
\text { 18. Psilenchus aestuarius } \\
\text { 19. P. aberans }\end{array}$ & Ectoparasites & $\begin{array}{l}- \\
+\end{array}$ & $\begin{array}{l}+ \\
+\end{array}$ & $\begin{array}{l}+ \\
+\end{array}$ & $\begin{array}{l}- \\
+\end{array}$ \\
\hline $\begin{array}{l}\text { VII. Tylenchidae fam.: } \\
\text { 20. Tylechus filiformis } \\
\text { VIII. Heteroderidae fam.: } \\
\text { 21. H. avenae }\end{array}$ & $\begin{array}{l}\text { Endoparasitic-mi- } \\
\text { gratory } \\
\text { Cyst forming }\end{array}$ & + & ++ & $\begin{array}{l}+ \\
++\end{array}$ & $\begin{array}{l}+ \\
++\end{array}$ \\
\hline $\begin{aligned} \text { Total: } 8 \text { families } \\
21 \text { species }\end{aligned}$ & $\begin{array}{l}5 \text { trophic-parasi- } \\
\text { tic specialization } \\
\text { groups }\end{array}$ & 21 & 26 & 27 & 25 \\
\hline
\end{tabular}

It was highlighted the presence of species from the families Hoplolaimidae, Paratylenchidae, Telotylenchidae, Criconematidae, Neotylenchidae, Tylenchidae, present in the late spring-summer periods in various forms and biological stages extracted both from the soil and from the roots of plants (fig. 10). All species were classified according to parasitic trophic specialization 
in 5 groups, with the predominance of endo- and ectoparasitic forms of absorbent bristles, according to the mode of adaptation, growth phase, biotope, environmental factors $[4,8,19,20$, 21].

At the same time, the corn was monitored for the presence of insect species associated with soil nodule complexes and equal environmental conditions. Table number 3 estimates the species of harmful insects detected in corn, practically in all the researched areas, with different degree of disease and numerical density. They are visible from the first phases of vegetation, as invasive pests from the soil, which caused significant damage to young seedlings: wire larvae of the genus Agriotes spp. high attack estimating values of 25-30\%. With the maturation of the plants, the larvae of the nocturnal owl species (Agrotis segetum, Autographa gamma, Heliothis armigera) are gradually associated, which also register an advanced attack of 15-25\%, comparative to the sectors, then the corn borer (Ostrinia nubilalis) is associated, which had a high attack rate of 10-20\% (figures 8,9). Significantly, during the research period, in the sectors monitored for corn, was also reported the dangerous object of external quarantine for the Republic of Moldova - Diabrotica virgifera virgifera in the seed sectors, North area, Soroca district.

Table 3. Pararasitic entomofauna diversity established in corn during the vegetation period with invasive impact

\begin{tabular}{|c|c|c|c|c|c|c|}
\hline \multirow{3}{*}{ Name of the species } & \multicolumn{4}{|c|}{$\begin{array}{c}\text { Numerical density of pests detected on average } \\
10 \text { soil samples - } 100 \text { plants analysis }\end{array}$} & \multirow{3}{*}{$\begin{array}{c}\begin{array}{c}\text { Affection } \\
\text { degree }\end{array} \\
\% \\
\end{array}$} & \multirow{3}{*}{$\begin{array}{c}\begin{array}{c}\text { Infestation } \\
\text { level }\end{array} \\
\% \\
\end{array}$} \\
\hline & \multicolumn{2}{|c|}{ May - June } & \multicolumn{2}{|c|}{ July - august } & & \\
\hline & Larvae & Adults & Larvae & Adults & & \\
\hline $\begin{array}{l}\text { Cracking beetles (true } \\
\text { and false wire larvae } \\
\text { from Agriotes spp. } \\
\text { genus, Elateridae fam., } \\
\text { Esch., 1829;Tenebrioni- } \\
\text { dae fam., Latreille, } 1802\end{array}$ & 4 & 3 & 2 & 3 & $15-20$ & 10 \\
\hline $\begin{array}{l}\text { Corn leaf weevil -Tany- } \\
\text { mecus dilaticollis, Cur- } \\
\text { culionidae fam., Gyl- } \\
\text { len., } 1834\end{array}$ & 3 & 6 & - & - & 25-30 & 15 \\
\hline $\begin{array}{l}\text { Owl species Agrotis } \\
\text { segetum Schiff., 1775; } \\
\text { Autographa gamma } \\
\text { L., 1758; Heliothis } \\
\text { armigera Hüb., 1808, } \\
\text { Noctuidae fam, }\end{array}$ & 3 & 7 & 12 & 17 & $20-40$ & 18 \\
\hline $\begin{array}{l}\text { Gryllotalpa gryllotalpa, } \\
\text { Gryllotalpidae fam., L., } \\
1758\end{array}$ & 3 & 6 & 2 & 2 & $5-7$ & 8 \\
\hline $\begin{array}{l}\text { The black corn bee- } \\
\text { tle -Pentodon idiota, } \\
\text { Scarabaeidae f., Herbst, } \\
1789\end{array}$ & $\mathbf{0}$ & 4 & 7 & 4 & $7-10$ & 5 \\
\hline
\end{tabular}




\begin{tabular}{|c|c|c|c|c|c|c|}
\hline $\begin{array}{l}\text { May beetle (white } \\
\text { larvae)- Melolontha } \\
\text { melolontha, Scarabaei- } \\
\text { dae fam., L. } 1758\end{array}$ & 5 & 3 & - & - & $5-7$ & 7 \\
\hline $\begin{array}{l}\text { Corn borer -Ostrinia } \\
\text { nubilalis, Crambidae } \\
\text { fam., H, } 1796\end{array}$ & 0 & 12 & 33 & 14 & $10-20$ & 30 \\
\hline $\begin{array}{l}\text { Western corn rootworm } \\
\text {-Diabrotica virgifera, } \\
\text { Chrysomelidae fam., } \\
\text { LeConte, } 1868\end{array}$ & - & - & 15 & 7 & $5-10$ & 5 \\
\hline $\begin{array}{l}\text { Total: } 12 \text { species; } 8 \\
\text { families. }\end{array}$ & $3-5$ & $3-12$ & $2-33$ & $2-17$ & $5-40$ & $5-30$ \\
\hline
\end{tabular}

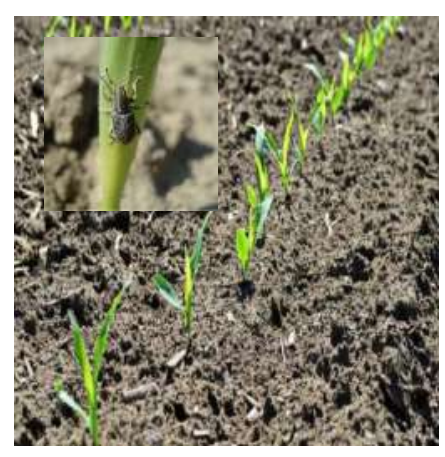

Figure 8. Affections caused by Tanymecus dilaticollis beetles

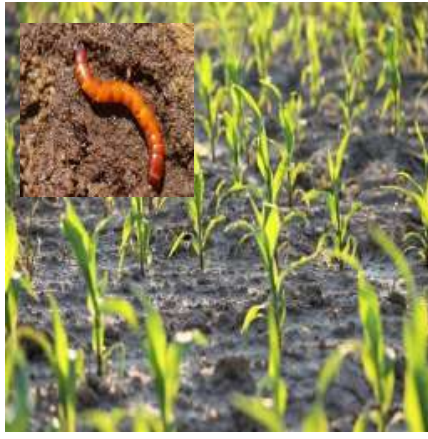

Figure 9. Corn contaminated with helminthiasis associated with wire larvae from Agriotes spp. genus

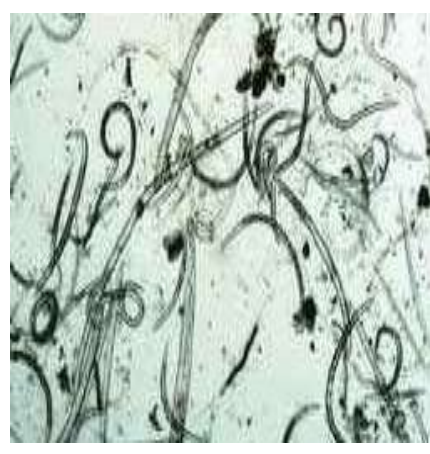

Figure 10. Associations of nematodes extracted from corn samples, analyzed under the microscope

\section{Conclusions}

Successful management of the pests estimated in those studies ensures the implementation of a permanent phytosanitary control program and integrated prevention and protection procedures, which includes a number of ways to regulate the number and reduce the impact of invasive parasites. The helminthological and entomological phytosanitary investigations results, carried out in 2019-2020 on corn cultivation, estimate the indices of diversity and structure of invasive nematodes communities and harmful insects from the soil, with comparative establishment of seasonal parasitic impact, vegetation phases, cultivation technologies, ecological areas.

Following the evidence surveys and helminthological analyzes performed on corn, the degree of infestation was established, by estimating the comparative indices of numerical density (D. n.), in variable values on areas of 15-280 ex./100 g soil, with the prevalence of numerical numbers more abundant by $25-30 \%$ during May-June, comparative to July-August. Frequency indices (F \%) of attack level, intensity (I \%) and extensiveness of helminthological and entomological diseases in corn, estimated values of 5-40\% in the critical phases of germination-maturity, which is facilitated by the plants sensitivity by accumulations of biological reserves in 
autumn period in the soil.

It was found the parasitic nematodes diversity and structure in corn culture in number of 32 species included in 8 families of the Tylenchida order, distributed according to the investigated areas and classified into 5 trophic specialization groups, with estimation of endo-ectoparasitic migratory species from families: Hoplolaimidae, Paratylenchidae, Telotylenchidae, Criconematidae, Neotylenchidae, Tylenchidae Pratylenchidae widespread abundantly in virtually all areas investigated. At the same time, the diversity and the level of associative disease of the complex insect pests in the soil were established in a number of 12 species included in 8 genera and three orders of the Insecta class, noted for severe challenges to corn roots and stems, reported in all phases and the investigated plantations, where the true and false wire larvae, Elateridae, Tenebrionidae, proved to be more aggressive; corn weevils, Tenebrionidae, owl species, Noctuidae; the black beetle and the corn beetle, Scarabaeidae; the larvae of the corn borer of the Crambidae family and the detection of the dangerous quarantine species of the western worm of the corn roots - Diabrotica virgifera, Chrysomelidae, on the northern areas.

The studies were carried out within the research project no. 20.80009.7007.12.

\section{Bibliography}

1. Andrassay I. Evolution as basis for the systematization of nematodes. Budapest, London:Pitman Publishing, 1976, 288 p.

2. Baldwin J. G., Nadler S. A., Adams B. J. Evolution of Plant Parasitism among nematodes. Annu. Rev. Phytopathol. 2004, V. 42, p. 83-105.

3. Busuioc, M. Entomologie. Chişinău: UASM. 2004, p. 102-136.

4. Decramer W., Hunt D. Structure and classification plant nematodes. Plant Nematology, 2006, p. 97-118.

5. Moraru Ș. Tratat de fitotehnie, cultura plantelor de câmp, cereale. Iași: Dosoftei, 1999, p.12 28.

6. Nesterov P. Substituirea calitativă a complexelor fitonematodice din agrocenoze sub influienţa mijloacelor de luptă agrotehnice. Culeg. Diversitatea şi ecologia lumii animale în sisteme naturale şi antropizate. Chişinău, 1997, p. 48-61.

7. Oltean I., Perju T., Timuş A., Insecte fitofage dăunătoare ale plantelor cultivate. România, Cluj-Napoca: Poliam, 2001. 285 p.

8. Perry R.N., Moens M.M. (eds). Plant Nematology. Cabi. London U. K., 2006. 440 p.

9. Perry R.N., Wright D.J., Blaxter M.L., Robertson W.M. The cuticle. Free-Living and Plant Parasitic Nematodes. In: Perry R.N., Wright D.J., editors. Wallingford, UK: CAB International. 1999. P. 25-48

10. Perju T., Lazări I. și col. Entomologie agricolă. București: Editura Didactică și pedagogică, 1983. p. 429.

11. Pîrvan P., Maticiuc V., și col, Recomandări privind cultivarea porumbului în Republica Moldova, Paşcani, 2019. 440 p.

12. Romaşcu E., Nematozii plantelor agricole şi combaterea lor. București: Ceres ,1973, 120 p.

13. Tălmaciu M., Tălmaciu N. Entomologia Agricolă ID. Iași: UȘAMV „Ion Ionescu De La Brad” 2014. $181 \mathrm{p}$.

14. Starodub V. Fitotehnie, Manual didactic, Chişinău: UASM, 2015, p. 245-304.

15. Siddiqi M.R. Tylenchida: parasites of plants and insects. 2nd Edition. CAB International, Wallingford, Oxon, UK, 2000. 848 p. 
16. Siddiqi M. Tylenchida. London, UK: Commonwealth Agricultural Bureaux. Parasites of plants and insects, 2000, p. 123-148.

17. Vasilică C. Porumbul în fitotehnie., București: Editura Didactică și Pedagogică, 2003, pag. 423.

18. Бей-Биенко Г. Я. Об общей классификации насекомых. Энтомологическое обозрение. Москва: Высшая Школа. т. ХІІ, № 1. 1966. 495 с.

19. Деккер Х. Нематоды растений и борьба с ними. Москва, 1972. 443 с.

20. Никишичева К., Фауна фитонематод озимой пшеницы в различных почвенно климатических зонах Украины. Vestnik zoologii, Kiev. 2012, т. 36, nr. 3, с. 95-97.

21. Пойрас Л., Пойрас Н., Юрку-Страистару Е., Бивол А., Боинчан Б. Анализ видового разнообразия сообществ фитонематод озимой пшеницы некоторых районов Р. Молдовы. Межд. Конф. «Селекция» Бельцы, 2014. Р. 437-443.

22. Плавильщиков, Н. Определитель насекомых. Москва: Топикал, 1994. 543 с.

23. www.incda-fundulea.ro

24. www.doctorplant.ro

25. www.agro-magazin.ro

26. www.porumbeni.md 